Mandy Kretzschmar

\title{
Still Europeans? - Australian Self-Understandings in the Administration of Papua New Guinea in the 1960s
}

This article is concerned with the correlation between the fabric of Australia's national identity (or multiple identities) and the country's foreign and colonial policy in the 1960s, and critically reconsiders the interrelations between Australian expatriate and indigenous communities in Papua New Guinea (PNG) through an analysis of modes of representation.

The post-war period was characterised by an anxious rearticulation of what it meant to be distinctively Australian. This process took place not only within Australia's geographical borders, but also beyond, in Australia's external territories. Surprisingly, it was in the colonial context of bringing Australia's administrative role in Papua New Guinea (PNG) to a close that Australians continued to envision themselves primarily as 'Europeans'. International pressures, as much as the domestic government's intention, had induced a push to assume a new role in the Pacific region. The 1950s marked an end to imperial consolidation, and triggered a successive wave of decolonisation in Asia and Africa. As a result, Australia's 'white' and mainly British self-definition dwindled in importance and potency (Meaney 2008: 383). The traditional Anglo-Australian relationship declined as Britain turned to its immediate European neighbourhood. Moreover, on the national level, there emerged a greater sense of ethnic and cultural plurality with mounting pressures to provide indigenous Australians with equal rights. Forced to react to these changes - at both international and national level - Australian policymakers, the press, and other key players, were tied into the struggle over national re-definition abandoning the idea of racial exclusivity. These processes of moulding and publicising new national identities can be retraced in regard to Australia's continued responsibilities in PNG.

If Australia was as occupied with its self-definition as suggested, why then was the category 'European' still frequently deployed as a self-definition? This contradiction might be partially explained by the 
fact that racial categorisation had become dangerously provocative. The experience of the Holocaust was a reminder to how ideas of race had been misused to legitimise discrimination, slavery, and even genocide. Thus, race lost its value as an organising principle that explained differences in appearance, character and behaviour. This renunciation initiated a search for substitutes and the invention of new labels of identification. Rather unexpectedly, the 'European' emerged as an essential category in the Australian context. Although the self-label had previously held a decisive role in an empowering framework of identification that was articulated and sustained in Australian mainland press coverage, it had always remained just one among a variety of identifications for Australians and their perceived Others. Racial categories of 'white' and 'coloured' had proven more essential in substantiating claims of privilege in its external territories. By the 1960s, the term 'European' was almost exclusively applied to the expatriate community. This finding is in need of historical investigation, as the exclusive deployment cannot be explained through the obsolescence of racial categories alone. The term offered flexibility of interpretation, the capacity to express a common sense of belonging, and even a means to consolidate authority.

Historical research has assessed the nature of Australia's colonial governance, the impact of imperial rule on PNG and its indigenous peoples, and the territories' subsequent development as a self-governing nation. Both Nelson (2000) and Denoon (2005) argue that strategic interests impinged on the relations between the indigenous population and Australian settlers, affecting the settlers' self-understanding as Australians. Further, Clive Moore, Doug Munro and Jacqueline Leckie have been written on the colonial conditions of employment and the subsistence of paternalistic attitudes in managing indigenous labour (Moore et al. 1990). These inequalities were expressed in social categories of belonging as with the 'European'. More recently, scholars have been concerned with how social knowledge has been produced by means of representing, in detail, the perception of Pacific Islanders through Western eyes and the functionality of these images in the interest of the coloniser (e.g. Stella 2007).

This article feeds into this vein of scholarship. It aligns with postcolonial studies concerned with the discursive framing of the indigen- 
ous Others as opposed to the European (or Australian) Self (Selves). The article draws on the analysis of untapped primary sources from the Australian mainland press which provide an exceptional, 'doubledistanced' perspective on the Other, since the contributions were written by Australian correspondents (predominantly) located on the mainland about their fellow countrymen governing PNG and its indigenous peoples on-site.

\section{Australia's Post-War Administration of Papua New Guinea}

The post-war decade marked a crucial turn in Australia's policy towards its external territories. The collaboration between Australians and Indigenes against the Japanese had evoked a sense of obligation toward the indigenous population in the aftermath of the war. The Menzies government was willing to take on greater responsibility to precipitate political, economic and educational development. Australia's new portfolio entailed financial support to pave the way towards self-determination. This turning course of action manifested a will to enhance the situation of PNG's indigenous peoples, without setting a target date for independence. Australia's modus operandi was also guided by its own interests - for security in the surrounding Pacific area, a stable government in the territories, and nationally determined interests in agriculture and mining (Denoon 2005: 26). To enforce these interests, Australian policy makers preserved as much flexibility as possible with regard to the territories' future.

Indigenous participation in politics constituted a key component in preparing PNG to manage its own affairs but access to political affairs was slow to evolve. Illiteracy and limited access to education impeded on the creation of an indigenous intelligentsia in the western sense. The Australian government extended educational expenditure, but not until the late 1960s did secondary education and tertiary training become available to a larger number of Papua New Guineans. While indigenous involvement in high-skilled positions occurred at a modest pace, the rapid increase in the establishment of local government councils marked a watershed in the preparation for future autonomy. Set out in the Native Local Government Councils Ordinance (1949-60), local councils introduced a large part of the indigenous population at a grassroots level to ideas of political authority and democratic politics. 
Apart from internal obstacles, external developments affected the move toward self-government. In the late 1950s, the Dutch departure from West New Guinea became imminent. As the dispute with Indonesia intensified, the Dutch hastened the decolonising process in their administered part of the island. This change in policy held major implications for Australian rule in the eastern part. Menzies had a vital interest in helping to secure Dutch control of West New Guinea (renamed Papua), as the territory constituted a strategic buffer against South-East Asia. A takeover of Papua would translate into sharing a large land border with a politically instable Indonesia that displayed strong communist influences, which might spread into the Australian controlled part. The West New Guinea crisis raised Australian awareness that PNG's progression towards independence had to be quickened. This sense of urgency promoted a policy shift when West New Guinea passed into Indonesian control in 1962.

PNG's path toward self-government was marked by Australian decolonisation, international pressures as well as the increasing indigenous participation in politics. Bearing witness to these developments, the portrayal of the indigenous peoples and the articulation of self-understandings as Australians (or alternatively, 'Europeans') were subject to shifts. New political and social structures were instrumental in challenging traditional preconceptions and biases (Stella 2007: 208).

Two intertwined threads of discussion in the Australian media coverage of PNG will be examined: the repeal of legally enforced discrimination, with an additional section dealing in detail with the revision of the liquor laws, and the preliminary steps towards self-government, including perspectives on indigenous political participation.

\section{The End of Discriminatory Legislation - The 'European' as Abandoned Role Model}

Discrimination - cultural, racial or administrative - was a precondition of colonial authority. To assert power and control, social hierarchies had to be established by means of differentiation and representation, and by articulating understandings of both the Australian Self and the indigenous Others (e.g. JanMohamed 1986; Spivak 1988). The implementation and enforcement of discriminatory legis- 
lation against the indigenous populaces, and their spatial segregation in urban areas, was once seen as crucial to maintaining these social hierarchies and alleviating fears of violent resistance. Supposedly, this attitude became obsolete as the post-war period saw the development of a new awareness that colonised peoples had the right to self-determination. Australian policymakers were faced with the challenge to develop policies and to manage local change that would allow for their gradual withdrawal. In theory, legally enforced discrimination was irreconcilable with the aim to grant the indigenous peoples equal rights. Still, the Australian government remained reluctant to rescind regulations that ensured social boundaries that benefited the expatriate community.

In the mainland Australian press, the government's reluctance to abandon discriminatory legislation provoked considerable controversy. The left-leaning Nation criticised the Menzies Government for its "arrogant dogmatism" and paternalism. Reiterating the position of The Australian Worker, Nation argued that Paul Hasluck, Minister for Territories, acted in the settler community's interests. The Nation critically condemned the region's cultural inequalities and identified them as a core obstacle in the development toward self-government:

The major divisions of interest in New Guinea, such as those between employers and employees, between government and the governed, between the privileged and the unprivileged, [...] still coincide to a great degree with the basic distinction between European and Papuan. [...] (T)here remains a whole large body of restrictive statute law which applies only to Papuans, denying them basic liberties and rights which Europeans freely enjoy. (Groves 1962: 7-9)

The division between the colonial community of PNG as 'European' and the indigenous population as 'Papuan' was common practice. These distinctions generalised the cultural and ethnic diversity of the indigenous populations, while neglecting the contours and composition of each segment of society. The use of 'European' as a category of belonging can be attributed to its flexibility in describing a stratified society and its capacity to neutralise differences in ethnicity, class, gender and nationality. This act of artificial collectivisation emphasised a shared cultural and racial heritage that set 'Europeans' apart from the indigenous populations. The article understands this category as a signifier of supervisory authority over both the public and domestic aspects of indigenous lives. More specifi- 
cally, the category 'European' gestured to the main objective of colonial rule in PNG - that of controlled change (Wolfers in Latukefu 1989: 430).

This mode of deployment coincided with the general attitude that the concession of political autonomy to the indigenous community was to occur as a gradual transference of power. In this respect, the Australian government followed a dual strategy, changing discriminatory legislation and allowing indigenous participation in the political sphere, while simultaneously suppressing civil disobedience. Tensions over the alignment and agreement between political authorities in Canberra and residents in Port Moresby complicated these processes. Policymakers were aware that the regulations constituted an obstacle to indigenous development, but had reservations about ramifications once these organising principles of daily life were abandoned. In their view, Indigenes were not yet ready to be trusted with responsible government. This assertion justified the paternalistic interference in indigenous lives through the regulation of sexual interrelations, the implementation of curfews, the banning of alcohol, and other measures.

The Australian presses' ambivalence towards these interferences displayed in competing representation of the 'European'. The category's assigned attributions circled around the question of whether or not the indigenous peoples were to be considered mature enough for self-governance. By the late 1950s, the system of legal discrimination had come under review by international and domestic forces. As the pace of decolonisation accelerated worldwide, Australian politicians felt increasingly uneasy about their policy of institutionalised racism. Regulations such as the night curfew were gradually relaxed or completely abandoned.

The image of the ignorant, uncivilised Indigene, unfit for self-government still prevailed in sections of the press. It served to reinforce the idea of Australia as a responsible power guiding the process of decolonisation. Cultural diversity and a lack of education legitimated the view of the nationalist Bulletin that self-governance in the near future was impossible. However, as one of the articles favourably emphasised, progress had been achieved as a result of 'European' intervention:

The two areas have only one thing in common: they owe everything they have in way of law and order, progress, commerce, industry and 
transport (sea, land and air), to European initiative, organization and finance. (N.N. 1960:4)

Highlighting the benefits of Australia's colonial rule, while disregarding the policies of racial segregation, another Bulletin article argued that

(t)he natives of Papua-New Guinea are among the best-treated in the world today - if not the best. They have a free medical service [...]. They have free education [...] Europeans also pay the head-tax, medical and hospital fees, transport costs, education costs, legal and other costs. (Daika 1960: 16)

The benevolent undertone of being obligated to assist the movement toward independence is indicative of a greater desire to preserve the colonial hierarchy. Moreover, it reiterates an image of Australia as a mature, civilised nation.

After changes to the paper's editorial board had been implemented in 1961, The Bulletin gradually included critical commentaries that canvassed the adverse effects of racist attitudes on both the indigenous and the expatriate community. Assumptions about 'European superiority' and 'universal European literacy' were challenged because an indigenous educated elite gradually evolved. Expatriates' reluctance to arbitrate with Papuans, and their ignorance of indigenous customs and traditions, were charted as obstacles to be bridged to disintegrate the (racially motivated) segmentation of society. Wooten's editorial "The World's Most Generous Coloniser" (1965: 41-43) highlights a relapse into pre-war systems of racial organisation in PNG, but also discerns tendencies of transition in the socialising between Indigenes and expatriates:

In their hearts most Europeans in the Territory [...] have probably disliked the situation. [...] The number of natives who can count (on) real European friendships, backed by visiting between families, is still small, but is increasing. [...] As between Australia and New Guinea, the implication is that Australia is prepared to assist the people of New Guinea only to a standard of living markedly below its own.

Although Wooten aims to dismantle the idea of colonial benevolence attributed to the 'European' by emphasising a common humanity, traces of paternalistic dominance still persist. The figure of the 'European' still constitutes the driving force for social change. Those falling under the label are bestowed with a responsibility to bring about equality with the indigenous community, while the latter remain passive recipients. Thus, the discourse derives its power from 
how it continues to position the indigenous Papuans as in need of assistance. This article exemplifies the fact that politics of repression continued, as the 'European' held power over the course and pace of self-government. Interestingly, the category 'European' was preferably utilised as a substitute to the national label 'Australian', even though it was Australian policymakers who deliberated over PNG's political future.

The 'European' in PNG remained predominantly a bearer of authority and knowledge, both in the conservative and liberal press. However, the agenda of each paper determined the category's proposed deployment and its either predominantly positive or negative connotation. Whereas The Bulletin marginally conceded the problem of class and 'colour' divisions, The Australian Worker editorialised against the paternalistic administration of the Menzies government, warning that:

The argument that the Papuans are not ready for self-government is a dangerous one. The fatherly idea of giving them freedom when they are ready is very much like the dictator's line. (N.N. 1962:3)

Similarly, in the Nation, the 'European' was regarded with contempt, as the initiator of inequalities, who intended to maintain a culturally superior position. Between February and May 1964, anthropologist Murray Groves addressed these issues in a series of editorials. The author details the nature of relations between 'Europeans' and 'Papuans':

Papuans mingle with Europeans at official cocktail parties [...] Privately, however, almost all Europeans prefer to keep themselves apart. [...] Europeans have retreated to their private clubs, almost all of which still maintain the colour bar. [...] (t)he only relations between the races are those between master and domestic servant. (Groves 1964: 7-8)

Groves reiterates the growth of mutual friendships between both communities. In a similar way to Wooten, he approves of these tendencies, amidst prevailing racist attitudes towards the Indigenes. Both editorials invert the behaviour and attitude of the 'European', but their phrasing discerns a varying degree of rejection. The conservative press appears to be less concerned about the slow progress in creating a multiracial society. In contrast, the Nation's employment of the category and its besetting with meaning entailed 
vehement criticism against the preservation of colonial hierarchies of power.

\section{Lifting the Ban on Alcohol - Beware "European(s) of Low Moral Character"}

The discourse around public drinking was part of the general repeal of discriminatory laws that demonstrated the mounting support for Indigenes. An examination of the coverage of this contested issue reveals the social stratification concealed in the category 'European'. Prohibition for Indigenes was propagated with a focus on the morally corrosive features and health risks of drinking. The reasoning for denying Papuans access to alcohol exemplified this double standard. The expatriate community consumed more than double the amount of alcohol per capita than the Australian mainland population (Wolfers 1975:136-137). However, it was drunkenness among the indigenous population that was feared to cause violence and disorder. Papuans were regarded as unable to moderate their consumption. Blame for unrestrained and immoral behaviour on behalf of the Indigenes, as a result of alcohol abuse, was however also assigned to 'poor whites'. In July 1962, The Bulletin editorialised:

Many 'poor whites' on the fringes of both native and European society are not above sharing and selling their liquor with natives. [...] He (a senior native clerk) acquired a taste from surreptitious handouts from a European of low moral character in return for his services as gobetween procuring girls. [...] In Melanesian eyes alcohol is a status symbol just as much as the wearing of shoes. (Bogobada 1962: 1718)

'White pauperism' was a problem that occurred in colonies across the globe, for instance in India and South Africa, attracting considerable scholarly attention (e.g. Stoler 2002; Lange 2003; Mizutani 2006). In PNG, the actual presence of 'impoverished whites' was scarcely addressed in public. As Stoler (2002:26) discusses with relation to India, the fact that a section of the 'European community' lived on the edge, discloses how European lower class communities tangibly occupied the "limits of white prestige" and posed an imminent threat to "colonial control". Whereas the category 'European' emphasised unity, the distinction of 'poor whites' unveiled social tensions and cleavages within the expatriate community. 'Poor whites' could transgress colonial normativity. In the above-men- 
tioned editorial, the "European of low moral character" supplied alcohol to the 'natives'. In so doing, they undermined the project of imperial education and violated the laws implemented to uphold a hierarchically organised social order. Moreover, in possibly accepting sexual favours in return for providing Indigenes with alcohol, these 'Europeans' further infringed on ideas of morality and racial segregation.

Legal access to alcohol marked a symbolic step in the lead-up to self-government. The relaxation of laws in November 1962 would further relieve the indigenous community of the remnants of colonial paternalism. The media coverage of the debate over allowing $\mathrm{Pa}-$ puans to consume alcohol legally illustrates the instability of attributions underlying the classification of the 'European'. Shifts in meaning disclose its function as a site of negotiating different opinions. Between November 1961 and March 1963, The Bulletin published a series of articles that addressed the lifting of prohibition. "Near-Beer for New Guinea" (1961:26) discussed first proposals of how to introduce Indigenes to alcohol. Employing images of racist ridicule, objections were raised as "some natives are still eating each other and beer would increase their appetite". This propagation of stereotypes of cannibalism operated to dehumanise Indigenes and to emphasise their assumed immaturity. The same editorial rebuked "Europeans" for profiting by illegally supplying Indigenes with alcohol. The acknowledgement of the social stratification among those subsumed under the category, discloses that some 'Europeans' defied the law and themselves were as much in need of 'disciplining' as the 'natives'.

Despite earlier objections, The Bulletin endorsed the decision to grant Indigenes access to alcohol, while appealing to them to display repression and responsibility in their consumption. In September 1963, the editorial "Drinking or Discrimination" revisited the topic, concluding that although discriminatory laws had been repealed, "the sense and practice of racial discrimination" had not been removed. Incidentally, The Bulletin reverts to traditional stereotypes in this article, sympathising with the 'European' reasoning that

(i)t would be foolish and unreasonable to expect a European to sit in an hotel lounge and drink next to an unwashed primitive bush native. [...] most Europeans have taken refuge in their clubs [...] (1963:9). 
Again, 'natives' are flagged as Others, portrayed as incapable of complying with 'European' criteria of cleanliness and civilisation. This evoked incapability works to justify prevailing racist attitudes and the 'European's' aversion to socialising with the indigenous population. Moreover, this mode of reporting displays the replacement of one set of stereotypes with another that proves more efficient. The portrayal of Papua New Guineans as severe drinkers could not be sustained, thus the text reverts to other derogatory stereotypes of the uncivilised, unclean savage.

In sharp contrast, another editorial in Bulletin posits that the 'Europeans" refusal to accept 'native drinking' was at the core of extant discrimination. As the article's author and the paper's editor, Peter Hastings, notes:

New Guineans wanted to prove to Europeans that they could be trusted with their newly granted privilege [...] (T)he European has not accepted native drinking in any way at all. [...] The real answer lies with the Europeans themselves. What is needed is apparently the impossible - a change of heart. (1963:20)

Ambivalent representations of the 'European' within the discourse on public drinking are testament to the functionality of this category in marking social boundaries, setting a political agenda, and framing responsibilities. The dichotomy between 'European' and 'native' was maintained, yet these categories were fluid. This is evident in the changing portrayal of both groups in the 1960s. Through the lens of the Australian conservative mainland press, Papua New Guineans became portrayed in less derogatory terms, discussed as being capable of civilised moral alignment, as exemplified by their moderate drinking behaviour. This new terminology represented a change in the colonial discourse, which had once relied on an antithetical fixed Other (Bhabha 1994: 94). Past attributions of racial superiority, morality and intellect were partially abandoned and other characteristics were constructed in the process of assuming a new political agenda.

The fluid and contradictory meanings of the category 'European' reveal the realignment of social relations and the accoutrement of new responsibilities in preparing the indigenous community for self-government. The category could be linked to ideas of paternalism while simultaneously describing those people subsumed under the classification as holding onto out-dated racist attitudes. This ambiguity ex- 
poses the fragility and social cohesiveness among those people categorised under this contested term. The softening of the category 'European' did not evoke an apparent strengthening of 'Australian' as a more self-conscious, national category. Instead, it marked a tendency in the Australian mainland press to distance itself from the settler community in PNG.

\section{Indigenous Political Participation - Maintaining "Private Interests of the European"}

Australia was unable to prevent the Territory's political development as the international community was closely watching PNG's progress. The mainland press addressed the hesitancy of Australian policymakers in line with the existing political position of the respective papers. The Australian Worker and the Nation criticised the policymaker's reluctance to embrace change at a quicker pace. Their reporting agenda was directed at displaying the prejudices of the expatriate community and criticising their de facto prolongation of colonial practices. In contrast, The Bulletin de-emphasised governmental shortcomings in the gradual transfer of authority by clinging to colonialist representations. Thereby, notions of the 'European' as instructor and role model for the Indigene perpetuated questionable ideas of benevolence and humanitarian obligation. The expatriate's positive effect on the 'native' is addressed in "Forthrightness on New Guinea" (Fuzzy-Wuzzy, The Bulletin, 1960):

Every European plantation or farm is an unofficial demonstration-centre for the natives of the area, and native interest in cash-cropping is best stimulated by establishment of European properties in the area.

The seeming dedication to acting in the Indigene's interest diverts from the intention to expand 'European' influence and investment. Here, the focus is upon illustrating the 'European"s willingness to provide knowledge and training to induce economic growth. The subtext implies that the Australian government prioritised controlled economic advancement over political development. A major reason for this prioritisation was that influential trading and mining companies were Australian-owned, and substantially contributed to the Australian economy (Lal et al. 2000: 331). The gradual relinquishment of political power fuelled economic anxieties over whether the "private interests of the Europeans would be maintained", a topic 
raised by "Fuzzy Wuzzy" in a subsequent article in The Bulletin entitled "Insecurity in New Guinea" (1960). The public dialogue over those fears of takeover and loss of control indicates that governmental provisions to broaden indigenous rights were tangibly impinging on the lives of the expatriate settlers unwilling to relinquish their status. This was severely criticised in the liberal media. The Nation conceptualised the image of "European pressure groups" who "compete for economic resources, such as land, labour and capital" with Papuans, but receive preferential treatment by Hasluck's policy (Groves 1962: 7-9). Their exertion of political influence is understood as contributing to the maintenance of the cleft between the Papuans and the expatriates in terms of access to wealth, education and power. Several parallels can be drawn between the coverage of the Nation and The Australian Worker, both emphasising the need to promote indigenous political involvement. Nevertheless, the label's almost complete absence in the coverage of The Australian Worker is striking. The 'European' barely featured as a minor character; nor was it an intermediary between the 'Papuan' (as worker or employer) and the 'Australian Government'.

International intervention in the form of UN Visiting Missions, local pressures, and the unfolding West New Guinea conflict added a sense of urgency to the project of decolonising PNG, and animated discussion in the mainland press. The Bulletin generally advocated indigenous political participation, albeit at a gradual pace. In reporting on the upcoming election of the first House of Assembly (1964), the paper repeatedly called attention to political inexperience among the indigenous electorate, speaking of a possible "future administrative embarrassment". However, they also addressed the possibility that

the more experienced European politicians, both official and elected, may be expected to exploit to the optimum the distrust of the Highlanders for the Islanders, and the latent contempt with which the Papuans and New Guineans regard each other.

The tone of the article "New Guinea's Election" (1964:22-26) vacillates between affirming the idea of 'European superiority' and evoking sincere concerns that educational inequalities will make the elected indigenous members of the new House of Assembly vulnerable to political corruption by 'European politicians'. It illustrates a tension between propagating Australia's willingness to transfer legal 
power - a gambit to indicate the nation's realignment in the AsiaPacific region - and an unaffected superiority complex with regard to the indigenous population.

From the early 1960s, the Australian government took measures to quicken the pace of indigenous participation in politics. Further steps toward self-government were taken after Charles Barnes succeeded Hasluck as Minister for Territories (1963), such as the World Bank Seminar (1965) and the election of the second House of Assembly (1968). However, none of these received considerable media attention. The inevitability of the decolonising process seemed to turn press interest to other, more immediate, domestic matters. Following this, reports on PNG in the second half of the decade declined both in the conservative and the liberal press. Coverage predominantly emphasised the injustice of the two-wage policy and the appreciation of indigenous mimicry of 'European' habits and behaviour. The Nation's intellectual contributors targeted the continued existence of discriminatory legislation and the practice of segregation, dissecting the society of PNG as one of

two worlds: the world of white skins (expatriates; Europeans or overseas officers are some of the euphemisms used) and the world of dark-skinned (natives, indigene or local officers). For the most part the worlds are completely separate. (Inglis 1968: 5-7)

On a similar note, Hank Nelson summarised the observations of a meeting held on race relations in 1966:

Presumably the European, who thought he earned his privileges and now it was up to the Papuans to develop their own material environment, was representative of a large number of Europeans not at the meeting. (Nelson 1966: 8-9)

Both articles scrutinised the social and economic cleavages between the expatriate and indigenous populations, divisions that continued to coincide with patterns of racial relations in colonial society. However, the press tendency to deliberately choose a vocabulary of deviance and affinity that largely refrained from references to national affiliation is in need of clarification. In the Nation's reporting the deployment of the category 'European' can be conceived of as part of a process of exposing the discursive reaffirmation of ideas of racial differences. 'European' is not synonymous with 'white'; however, the category implies a racial coherence and cultural closeness among its subsumed members. The self-aggrandising narrative of the 'Euro- 
pean' as intellectually and morally superior, as much as prevailing attitudes of high-mindedness and arrogance, are exposed as myth, and condemned as a means to retain control over the indigenous Other. The unmasking of these earlier attributions and their assignment to the category 'European' in both the Nation, and, later, The Bulletin, evinced changed social orders as PNG moved towards independence.

\section{Conclusion}

Australia's unease about the direction and pace in leading Papua New Guineans to self-government, coupled with aspirations to secure its future in the Asian-Pacific region, reverberated in a versatile deployment of the category 'European' in the press. The comprehensive term was frequently applied as a figuration of identity for the expatriate community, presumably as a consequence of the renunciation of racial categorisations. In the search for substitutes to negotiate affinity and assert difference, the term 'European' gained in significance as an essential category that offered enough flexibility and plasticity to manage different sections of the settler community. Simultaneously, the broadness of the category facilitated distancing from the Australian mainland population by deliberately refraining from emphasising national affiliation. The diverse and contradictory attributions employed across the mainland press illustrate the functionality of the 'European' as a signifier of power, which was either juxtaposed with an image of the needy Papuan/native, or condemned as a remnant of colonialism. Whereas positive connotations of the 'European' - as role model and instructor for the Indigene operated to justify Australia's gradual pace in decolonising PNG, negative attributions served to challenge western notions of dominance. The presence of competing representations, linked to the political view of the respective papers, displays how changes in the contours of belonging were slow to evolve. In the conservative press, the 'European' remained linked to ideas of paternalism, benevolence, morality and intellectual superiority. These colonialist representations were subject to vehement criticism in the left-leaning press, which increasingly challenged an out-dated understanding that still underpinned politics of exclusion. Left-leaning papers, contrasted them with representations of the exploitative 'European businessman', the arrogant 'European settler', or, as in the case of The 
Australian Worker, by abstaining from using the category 'European' almost completely. The Nation's editorial board was sympathetic to anti-colonialism, and argued that if Australia wanted to become a partner in the Asia-Pacific region it needed to change its foreign policy and redefine its white British self-understanding. Reluctance and anxiety marked both the process of transferring power to the indigenous peoples of PNG and the gradual shift towards a new understanding of the 'European' in the Australian mainland press.

\section{Bibliography}

\section{Primary Sources}

Bogobada, 1962. "Drinking in New Guinea". The Bulletin, 21 July, 17-18.

Daika, 1960. "How New Guinea Natives Fare". The Bulletin, 7 September, 16.

"Fuzzy-Wuzzy", 1960. "Forthrightness on New Guinea". The Bulletin, 3 February, 45.

"Fuzzy-Wuzzy", 1960. "Insecurity in New Guinea". The Bulletin, 8 June, 7.

Groves, Murray, 1962. "The Reign of Mr. Hasluck". Nation, 5 May, 79.

Groves, Murray, 1964. "Was Mr. Hasluck Right?". Nation, 8 February, 7-8.

Hastings, Peter, 1963. "The Winds of Change in New Guinea's Pubs". The Bulletin, 16 March, 20.

Inglis, Amirah, 1968. "Tale of Two Cities". Nation, 8 June, 5-7.

Nelson, Hank, 1966. "An Outspoken Papuan". Nation, 28 May, 8-9.

N.N., 1960. "New Guinea's Future". The Bulletin, 10 August, 4.

N.N., 1961. "Near-Beer for New Guinea". The Bulletin, 25 November, 26.

N.N., 1962. "Thinking About New Guinea". The Australian Worker, 26 September, 3.

N.N., 1963. "Drinking or Discrimination". The Bulletin, 9 March, 9.

N.N., 1964. "New Guinea's Election". The Bulletin, 11 January, 2226.

Wooten, J.H., 1965. "The World's Most Generous Colonisers". The Bulletin, 27 February, 41-43. 


\section{Secondary Sources}

Bhabha, Homi, 1994. The Location of Culture. London: Routledge.

Denoon, Donald, 2005. A Trial Separation: Australia and the Decolonisation of Papua New Guinea. Canberra: Panadus Books.

JanMohamed, Abdul R., 1986. "The Economy of Manichean Allegory:

The Function of Racial Difference in Colonialist Literature", in: Henry Louis Gates, ed., "Race", Writing and Difference. Chicago: University of Chicago Press, 78-106.

Lal, Brij V., and Kate Fortune, eds., 2000. The Pacific Islands: An Encyclopedia. Honolulu: University of Hawai'i Press.

Lange, Lis, 2003. White, Poor and Angry: White Working-Class Families in Johannesburg. Aldershot: Ashgate.

Meaney, Neville, 2008. "In History's Page: Identity and Myth", in: Deryck Schreuder and Stuart Ward, eds., Australia's Empire: The Oxford History of the British Empire. Oxford: Oxford University Press, 363-387.

Mizutani, Satoshi, 2006. "Historicising Whiteness: From the Case of Late Colonial India", ACRAWSA e-journal 2 (1), 1-15.

Moore, Clive, Jacqueline Leckie, and Doug Munro, eds., 1990. Labour in the South Pacific. Townsville: James Cook University.

Nelson, Hank, 2000. "Liberation: The End of Australian Rule in Papua New Guinea", The Journal of Pacific History 35 (3), 269280.

Spivak, Gayatri C., 1988. "Can the Subaltern Speak?" in: Cary Nelson and Lawrence Grossberg, eds., Marxism and the Interpretation of Culture. Urbana: University of Hawai'i Press, 271-316.

Stella, Regis, 2007. Imagining the Other: The Representation of the Papuan New Guinean Subject. Honolulu: University of Hawai'i Press.

Stoler, Ann, 2002. Carnal Knowledge and Imperial Power: Race and the Intimate in Colonial Rule. Berkeley: University of California Press.

Thompson, Roger C., 1998. Australia and the Pacific Islands in the Twentieth Century. Melbourne: Australian Scholarly Publishing.

Wolfers, Edward P., 1975. Race Relations and Colonial Rule in Papua New Guinea. Sydney: Australia and New Zealand Book Co.

Wolfers, Edward P., 1989. "For the First 'Generation...With No Personal Recollection of Australian Rule': Reflections on the Impact of Colonial Rule in Papua New Guinea", in: Sione Latukefu, ed., 
104 Mandy Kretzschmar

Papua New Guinea: A Century of Colonial Impact, 1884-1984. Boroko: University of Papua New Guinea, 417-457. 